Journal of

\title{
Education and Practice
} (JEP)

Smart Slate Game and Students Academic Performance in Educational Technology, University of Calabar, Nigeria

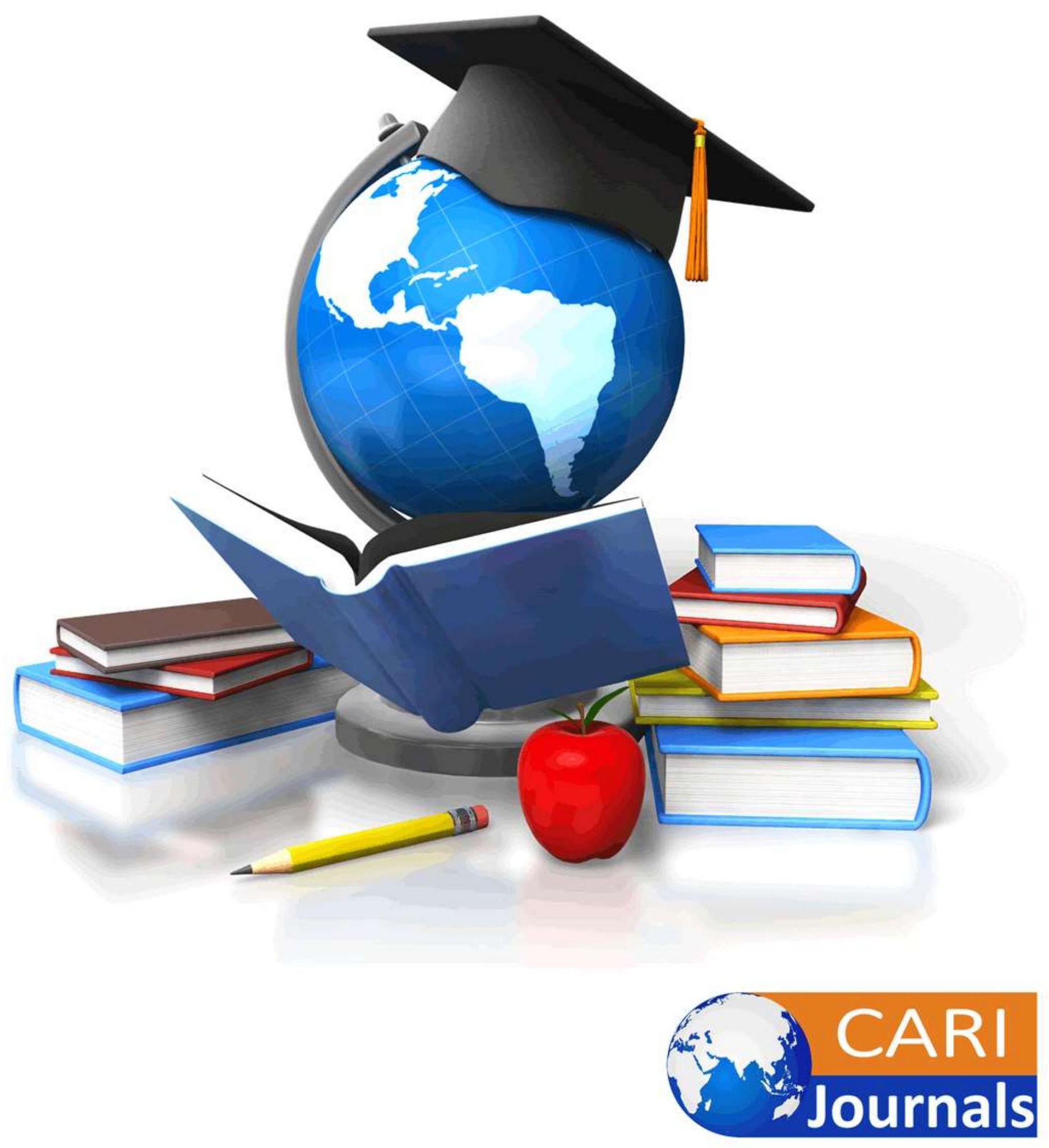


Journal of Education and Practice

ISSN 2520-467X (Online)

Vol.6, Issue No.1, pp 1 - 18, 2022

WWW.carijournals.org

\title{
Smart Slate Game and Students Academic Performance in Educational Technology, University of Calabar, Nigeria
}

\author{
Effiong, Abigail Aniefiok ${ }^{1}$, Ekpo-Eloma, Ekpo Omini ${ }^{2}$, Jacob Kirian James ${ }^{3}$ and Udoh, Victoria \\ Inebehe $^{4}$ \\ ${ }^{1,2}$ Department of Curriculum \& Teaching, Faculty of Educational \\ Foundation Studies, University of Calabar, Calabar. \\ abianiefiok@unical.edu.ng,joneseloma@unical.edu.ng
${ }^{3,4}$ Department of Educational Technology \& Library Science, Faculty of Education University of Uyo \\ kirianjames17@yahoo.com, vickyudoh91@gmail.com
}

\begin{abstract}
The study examined the effect Utilization of Smart Slate Game (SSG) on year two students' academic performance in Educational Technology in the University of Calabar, Nigeria. Two purpose of the study and two null hypotheses were formulated to guide the study, Quasiexperimental research design using pre-test posttest non-randomized control group design was adopted for the study. The population is made up of all Educational Technology students in the University of Calabar. A sample of 131 year two students of educational technology comprising of 66 students (26 males and 40 males) in the experimental group and 65 students (28 males and 37 females) in the control group were purposively sampled for the study. The Smart Slate Game and Educational Technology Performance Test (ETPT) were the instruments used for data collection. The results of the study were analyzed using Analysis of Covariance (ANCOVA). The results revealed that there is a significant difference in academic performance of educational technology students taught with smart slate game and those taught using expository method, there was also a significant difference in performance between male and female students taught using the Smart Slate Game, there was no significant difference in cognitive abilities of Educational Technology students when using Smart Slate Game. It was therefore recommended smart slate game technology should be used always to promote students academic performance in educational technology and that teachers should effectively design their lesson plans with Smart Slate Game to foster group task and have fun while learning.
\end{abstract}

Keywords: Utilization, Smart Slate Game Technology, Educational Technology, Students' Performance in University of Calabar

\section{Introduction}

Education is experiencing swift and radical changes in the $21^{\text {st }}$ century as a result of emerging technologies. This dynamism has created opportunities for technological innovations to be integrated into the pedagogical process for effective and satisfactory delivery of learning tasks within and outside the confinement of the classrooms. Qualitative approach to teaching and learning, which is in high expectations from educational stakeholders, places more demands on technology driven education geared towards bringing both learners and teachers to the realization 
Journal of Education and Practice

ISSN 2520-467X (Online)

Vol.6, Issue No.1, pp 1 - 18, 2022

WWW.carijournals.org

of educational objectives. Educational technology as reflected in different research journals and textual materials has brought to the fore various strategies and modes for realization of desirable goals in the teaching learning process. Among all these, many researches are still springing forth with findings on how to maximally individualized learning. The essence is to make pedagogy more of learner'-centered and at the same time fostering interactions among learners, materials and teachers. In the midst of this, it is expected that, what to learn should create fun and motivate learners to strive for more without deviating from the instructional goals. One of the teachings make teaching easy and learners interests captivated in delivery of effective instruction is the integration of Smart Slate Electronic Games Technology (SSEGT) lesson plan for the learners to interact with themselves using the Slate to attain instructional goals. Smart Slate Game Instruction involves the use of Smart Slate Electronic gadget, connected to the Computer system through Bluetooth or any wireless mechanism embedded with instructional content to facilitate learning. The operating distance to which Smart Slate Device (SSD) is connected to the computer system is about 32 to $10 \mathrm{~m}(33 \mathrm{ft})$. The Smart Slate Game is a product of Smart Slate that allows instructional designers to cushion the content of the instruction in line with the game, which is already programmed by the Smart Slate Company. The essence of Smart Slate Game in pedagogy is to create fun within the classroom and to motivate learners to learn with enthusiasm. McClarty $(2012)^{[1]}$ maintains that students' use of Smart Slate Electronic Game in learning assessment is expected to increase their learning outcome. According to de Smale (2015) ${ }^{[2]}$, a positive relationship exist between the use of Smart Slate Game and students' academic performance in Schools. To ascertain effect of Smart Electronic Game Technology as a supplementary element in collaborative learning, Rajan (2013) ${ }^{[3]}$ explain that Smart Slate Electronic Game require the adoption of high quality support structure, students' participation as well as the promotion of cognitive and meta-cognitive skills. Smart Slate Game could be used to solve problems, complete a task or create a product in a group. Hence, the teaching and learning process become relevant when using Smart Slate Game by allowing members of the group (classroom) to work together to realize instructional goals. Ritu (2015) ${ }^{[4]}$ maintains that when students use Smart Slate Game ingroup to learn, it assists in developing higher-level thinking, oral communication, selfmanagement and leadership skills. In view of this, Ke \& Grabowski (2009) ${ }^{[5]}$ in their study using a sample size of 125 , students divided into collaborative group (who were competing), the students took a test before and after the experiment and the research result indicated that playing Smart Slate game was more efficient than doing the traditional tasks.

To ensure that students perform better during group lesson, students' cognitive abilities on the use of Smart Slate Game were equally important. In the study of the impact of Smart Slate Game on students' performance, Hirumi \& Bai $(2010)^{[6]}$ indicated that there was significance in performance recorded in the group which played the Game. In a similar manner, Von, Meijden and Denessen (2011) ${ }^{[7]}$ examined the issue of students' cognitive abilities in the use of Smart Slate Game by experimenting on 235 students. One group was asked to create their own 'Smart Slate Game' while the other group displayed the existing game type. The results suggested that designing a game could be a better way to improving the cognitive abilities and increasing students' performance in pedagogy. Ayoud (2019) ${ }^{[8]}$ admits that students might ask questions during the Smart Slate Game session to help them structure their sentences or do their assignments before posting them.

The effectiveness in the application of Smart Slate Game into collaborative classroom assist students in breaking the gender disparity in learning. . This findings is also in line with Oluwatayo $(2011)^{[9]}$ who reported that males had a larger variance in Physics scores than females. Moreover, female students tended to outperform males among the low achieving students while male student 
Journal of Education and Practice

ISSN 2520-467X (Online)

Vol.6, Issue No.1, pp 1 - 18, 2022

WWW.carijournals.org

tended to outperform females among the high achieving students. Ke \& Grabow (2019) ${ }^{[5]}$ observed this in the study of 88 students drawn by gender into two groups. One played a Smart Slate Game and the other did not. He conducted a computer pretest and post test to access their knowledge, the result which initially proven male dominance was not significant regardless of the gender of students. It was affirmed in their experimental studies that playing Smart Slate Electronic Game Technology influenced their cognitive abilities and motivation in higher school learning. This, by implication, are the reasons the researchers adopted the study among the year 2 educational technology male and female students academic performance in the University of Calabar.

\subsection{Theoretical Framework}

The researchers considered two theories to support the variables under investigations. These are:

\section{The Cognitive Theory of Robert Meyer \& Roxana (2003)}

Robert Meyer and Roxana propounded the cognitive theory in 2003. The theory asserted dual channels, limited capacity and active processing skills in multimedia usage. They explained that the human working memory has two sub -components (visual and auditory) in parallel and can be more successful if both are used simultaneously for information processing. The duo illustrated that human brain does not interpret a multimedia presentation of words, pictures and auditory information in a mutually exclusive fashion but the elements (visual and auditory) to assist in selecting and organizing information dynamically to produce logical, mental construct in learning. This implies the choice of Smart Slate Electronic Technology, the instructor should fashion out its design of the Smart Slate with words and Pictures to improve both male and female learners cognitive ability to learning. With these, Meyer and Roxana (2003) concluded that the design principle would enable learners to build up their mental representation, interpretation and directory towards insightful learning.

\section{b. Lev Vygotsky Collaborative Theory of Learning (1962)}

A Russian teacher and psychologist Lev Vygotsky propounded this theory in 1962 . He asserted that students learn through interactions and communication with others. Vygotsky examined how our Social Environments influence the learning process using social interactive method. The result led to his conclusion that when an instructor creates a conducive learning environment for the learners to interact with each other through discussion, collaboration and feedback, it would promote active participation in research, sharing of results, final project report, and help a collaborative community of learners. Vygotsky (1978) supported this view that knowledge construction involves students to students and experts to students, instructional media to students' collaboration in real world problems, skills and experience shaped by individual culture. Therefore, it is worthwhile for an instructor to design instruction with Smart Slate Electronic Game Technology to facilitate learning in a group. This to Vygotsky would assist learners' to develop skills and motivations for learners to work as a team to realize their set goals.

\section{c. Walberg's Theory of students Academic Performance}

Herbert Walberg propounded this theory in 1981 based on empirical tested learning performance of over 3000 studies. He identified keys variables to high academic performance of students to be students' ability, motivation, age / development, quality instruction, classroom climate, home environment, peer group and exposure to media. This implies that 
Journal of Education and Practice

ISSN 2520-467X (Online)

WWW.carijournals.org

Vol.6, Issue No.1, pp 1 - 18, 2022

using Smart Slate Game (multimedia) in Collaborative Learning (peer group) cam improve students' performance.

\subsection{Empirical Framework}

Today's world is one that is largely composed of technology. In a relatively short span of time we have been immersed in a world of high-definition television, Facebook, YouTube, internet radio, "green" cars, outrageous thrill rides, 3-D technology, etc. But no area of technology has become as prominent as that of video gaming. According to Anand (2007) ${ }^{[10]}$, the penetration of video games into the United States alone is huge, with at least $90 \%$ of homes having children that have played (rented or owned) video games. This is a record level that continues to increase. About $55 \%$ of console players and $66 \%$ of online players are over 18. The college demographic seems to be the major group of gamers simply because they have a lack of parental supervision and they have more flexible schedules, allowing for more play time (Anand, 2007) ${ }^{[10]}$. As with any other innovation in society, the introduction of video games brought the question "What are the negative effects or consequences?" Smyth $(2007)^{[11]}$ notes that there seems to be an increased interest in research in the area of video gaming to answer this question. In undertaking the research, one main concern seems to be whether the playing of video games impacts academic performance in a negative or positive way and what are those consequences. A study carried out by Anand (2007) ${ }^{[10]}$ found a negative correlation between the amount of time spent playing video games and the GPA and SAT scores of students. This means that GPA and SAT scores decreased as time spent playing increased. However, Anand $(2007)^{[10]}$ did recognize the limitation of using SAT scores because they represent a one-time standardized score. Using GPA is more credible because it represents a continuous measurement of school performance. He also found that males were more prone to these results than females, because males tend to play video games more. Skoric, Teo, and Neo (2009) ${ }^{[12]}$ went one step farther and studied addiction to video gaming versus simple engagement in video gaming.

Although no definitive definition of addiction was given, they found that those addicted to gaming consistently performed negatively in the academic setting, while there was no negative correlation between time spent playing or engagement and academic performance. Skoric, Teo, and Neo (2009) ${ }^{[12]}$ also studied addiction (once again no definitive definition was given) and noted a decrease in school performance when the student was addicted to gaming. They found that gaming addiction physically impacts academic achievement because the student is too involved in the game to do homework or prepare academically. There are also others that have found decreased academic performance in relation to involvement in playing video games. Anderson and Dill (2007) ${ }^{[13]}$ studied video games and aggression and suggested that not only does gaming have an impact on performance directly, but it also triggers a higher level of aggression, which is often linked to problems in school and decreased academic performance.

Wack and Tantleff-Dunn (2009) ${ }^{[14]}$ also found a negative correlation between video games and students academic performance, although the relationship between GPA and academic performance in their study was not significant. Jackson et al $(2008)^{[15]}$ found that time spent playing games was a negative predictor of academic performance and that those who played video games more often had poorer grades than those who played less. A study conducted by Wood, Griffiths, and Parke (2007) ${ }^{[16]}$ using open-ended questions that encouraged participants to report different feelings about playing video games. Some of the negative 
Journal of Education and Practice

ISSN 2520-467X (Online)

www.carijournals.org

Vol.6, Issue No.1, pp 1 - 18, 2022 consequences indirectly related to school performance, in that participants reported often
missing lectures, skipping homework, etc. They also found that these consequences were more likely to impact males, because males play more often and were more likely to report losing track of the time while playing. In an experiment by Williams (2006) ${ }^{[17]}$, school performance increased after the participants dramatically decreased (limited time spent using technology to 30 minutes per day) their usage of all technology, including video games, he found that the excessive playing of video games (five hours or more per session) resulted in school grades that were below a 3.00average, and that time spent playing was a predictor of academic performance. They also suggested that video games indirectly lead to decreased performance through promoting violence. Finally, they noted that playing video games took time away from school activities, homework, social interaction, etc.

Effiong and Ekpo (2016) ${ }^{[18]}$ examined the interactive effect of PowerPoint instructional package on academic performance of Educational Technology students in the University of Calabar. One null hypothesis was formulated to guide the study. The study employed the pretest-post-test non-randomized control group design to select 180 Educational Technology students. Educational Technology Performance Test (ETPT) was the instrument used for data collection, with reliability co-efficient of 0.72 . The data from the respondents were analysed using analysis of covariance (ANCOVA). The finding of the study revealed that there was a significant difference between the performance of students taught Educational Technology using PowerPoint instructional package and those taught using the conventional expository method, in favour of those taught using PowerPoint instructional package. Based on the finding, it was recommended that PowerPoint instructional package should be used as an instructional tool to enhance students' academic performance in Educational Technology in the University of Calabar.

Ukwetang, Nja, Eneyo, Ambe and Etta $(2021)^{[19]}$ carried out a study to find out the usage of information communication technology ICT and students' academic performance in Tourism in selected secondary schools in Calabar Municipality in Cross River State. They survey research design was used and a sample of 200 respondents was selected; the study used a four (4) point scale questionnaire and achievement test on Tourism as an instrument for data collection. Independent t-test analysis was applied in testing the hypotheses formulated at 0.05 level of significance. The result obtain indicated that, there is a significant difference between the academic performance of student who study with and without internet; there is no significant difference between the academic performance of student who study with and without internet; there is no significant difference between the academic performance of student who study with and without computer games; there is no significant difference between the academic performance of students who study with and without email and there is a significant difference between academic performance of students who study with and without facebook. Based on the findings, recommendations were; they should be an inservice training for Tourism teachers on information communication technology to enhance the ICT skills of teachers to teach the student.

Okworo and Effiong (2020) ${ }^{[20]}$ study was on the use of teacher's made YouTube instructional video package and student's performance in Educational Technology in Faculty of Education, University of Calabar. Two research questions and two hypotheses were formulated to guide the study. Quasi experimental design was adopted. Sixty-four educational technology students were purposively used in their intact. One instrument was developed by the researcher Educational Technology Performance Test (ETPT). The data obtained from respondents was analysed using Mean and Standard Deviation and Analysis of Covariance 
Journal of Education and Practice

ISSN 2520-467X (Online)

Vol.6, Issue No.1, pp 1 - 18, 2022

WWW.carijournals.org

(ANCOVA) for research questions and hypotheses respectively. The findings of the result reveal that the use of teacher-made YouTube instructional package does not significantly affect academic performance of year one educational technology students. Recommendations were made to improve method of teaching educational technology. Integration of YouTube Video in teaching and learning should as a matter of urgency be adopted as a communication medium. Lecturers must keep pace with the new technologies in the classroom through regular attendance in workshop, conferences and in-service learning.

\subsection{Statement of Problem}

Educational Technology courses are increasingly become complex to the extent that most students lose interests in students in recent years. This could be attributed to the expository mode of teaching majorly adopted by lecturers in delivery educational technology courses in the Universities. Courses taught in Educational technology department should be interactional, captivating and creating maximum participations among students. However, due to the high level of abstraction associated with expository learning, students' interests drop leading to poor performance in Educational technology courses. This poor performance was feasible between $2016 / 2017$ to $2018 / 2019$ sessions in the University of Calabar, Department of Curriculum and Teaching (Educational Technology Unit) in Computer in Education Course (EDT-222), a course in Educational Technology. For instance, in 2016 /2017 academic session, 43 students sat for the course in EDT 222, 20 students passed resulting to $47 \%$ while 23 students failed representing $53 \%$. Since the percentage of students who failed is high as compared to the percentage of students who passed, it therefore means that students' performance in EDT 222 is low. Hence, this could be caused by the nature of presentation of the instruction that led to the dwindling performance in the course. Moreover, for students to experience improve performance, lecturers must employ modern techniques that encourage active learning such as Smart Slate Game Technology. In the opinion of the researchers, it could restore students' performance if properly utilizes as instructional strategy in teaching and learning educational technology courses.

\subsection{Purpose of the study}

The purpose of the study is to investigate the effect of Utilization of Smart Slate Games on year 2 educational technology students in University of Calabar, Nigeria.. Specifically, this study examined:

1. The difference in the academic performance of Educational Technology year two students taught with Smart Slate Game technology and those taught with expository method.

2. The difference in the academic performance of Male and Female year 2 Educational Technology students taught using Smart Slate Game.

3. The difference in the academic performance of Educational Technology year two students taught using Smart Slate Game technology and those taught using expository method based on low, moderate and high cognitive ability level.

\subsection{Research Hypotheses} study:

The following null hypotheses, at.05 levels of significance are formulated to guide the

$\mathrm{HO}_{1}$ : There is no significant difference in the academic performance of Educational Technology year two students taught with Smart Slate Game technology and those taught with expository method. 
Journal of Education and Practice

ISSN 2520-467X (Online)

WWW.carijournals.org

$\mathrm{HO}_{2}$ : There is no significant difference in the academic performance of male and female Educational Technology year two students taught using Smart Slate Game technology in the University of Calabar.

$\mathrm{HO}_{3}$ : There is no significant difference in the academic performance of Educational Technology year two students taught with Smart Slate Game technology and those taught with expository method based on low, moderate and high cognitive ability.

\section{$1.7 \quad$ Research Methodology}

The research design for this study was Quasi -experimental design using pre-test post-test non -randomized control group design. Quasi -experimental design is a design in which an independent variable is directly manipulated to measure its effect on the dependent variable and participants do not have the chance of being in the control or experimental group. Quasiexperimental design was chosen because the design establishes the effect of treatment (Smart Slate Game technology) on students' academic performance.

This comprised of students in their intact classes with mixed abilities. The pre-test provided a check on the non-random assignment of subject to groups. Moreover, comparison based on the pre-test performance provided further process of equating the research groups. The use of control provide the basis for comparison of the students' performance based on treatment given .The population for the study comprised of all the year two Educational Technology students in the Department of Curriculum and Teaching in the University of Calabar, Nigeria for 2018/2019 academic session. This comprised of 151 Educational Technology students (Source: 2019/2020 admission list from the Faculty Officer, Department of Curriculum and Teaching, Educational Technology unit).An intact class of year two under graduate educational technology students in the University of Calabar was purposively sampled and used for the study, which comprised of 66 students (26 males and 40 females) in the experimental group and 65 students ( 28 males and 37 females) in control group.

Purposive sampling was used based on the following criteria:

(i) Students have cleared their fees and were given class admit cards to participate in the study

(i) Have learnt Educational Technology Courses for more than a year

(iii) Have standard and workable android phones, laptops and computer devices to access the Internet.

The study used an instrument titled: Educational Technology Performance Test (ETPT) developed by the researcher. Educational Technology Performance Test contains (20) multiple-choice items with students' gender being indicated which covered sub-topics in the Course content. The selection of the sub-topics was guided by the Blue Print prepared by the researchers with each item having five (5) options lettered A-E. Each correct answer was scored five (5) and incorrect zero (0), giving a maximum of one hundred (100) marks and a minimum of zero (0).

The draft instrument "Educational Technology Performance Test" with 20- items was submitted for face and content validation to two lecturers in the University of Calabar. To test for the reliability of the instrument, the researchers conducted a trial testing study using 20 Educational Technology year two students from the Department of Curriculum and Teaching (Educational Technology Unit) who were not part of the sampled subjects. Split Half Method was used for a single administration of the Educational Technology Performance Test 
Journal of Education and Practice

ISSN 2520-467X (Online)

www.carijournals.org

Vol.6, Issue No.1, pp 1 - 18, 2022

(ETPT) instrument which yielded $(r)=.95$. The result $(r)$ was further subjected to Spearman Brown Prophesy Formula to produce a reliability coefficient of 0.97 . This result confirms that the instrument is reliable for use in obtaining the information for the study.

A comprehensive class list of 131 students was obtained and further divided into two groups (experimental and control). Students who fall under the serial number 1-66 form experimental group while students whose names fall under serial number 67-131 form the control group. In addition, students in the experimental group were further divided into subgroups (3 groups). They were taught using the different features in Smart Slate Game technology, out of 66 students who formed the experimental group, serial number 1-22 formed group 1,those in the serial number between 23-44 were taken to the second group (group 2) while the third category of students from 45 to 66 were assigned to group 3. Each of the group was taught using Smart Slate Game technology while the control group was taught using expository method.

To achieve this, students in the experimental groups were directed to the computers that the Smart Slate Device where connected via Bluetooth. The Smart Slate Game Technology began with the instruction using the Start $\rightarrow$ button. Students were instructed to use the pseudo pad to move the cursor to drag the features of the Subject matter- The Concept of Internet technology (EDT-222), click on the encyclopedia if they encounter difficulty and obtain energy for the cell. Every task, which was completely accomplished, led to another based on the stated objectives.

To create fun, the cursor often directed the students to whatever material they needed until the cell was completely built. Smart Slate Game has a simple formative evaluation to ascertain students understanding of the lesson contents. The control group was taught by the research assistants using the expository method for lesson delivery. At the end of the entire process, Educational Technology Performance Test (ETPT) was administered to the two groups (experimental and control) in two days from the period they were exposed to the lesson package. The researchers allow a period of One Hour to the two groups (experimental and control) to respond to the instrument under close supervision by the research assistants. After the test administration, the booklets were retrieved from the two groups and the scores were analyzed separately for the study. The entire procedures lasted for a month. The researchers used Mean and Standard Deviation to answer the research questions, while Analysis of Covariance (ANCOVA) was used to test the hypotheses at 0.05 level of significance. ANCOVA was used since the pre-test and post-test scores administered were used in the analyses to test the difference between two groups when having pairs of scores (pre-test-post-test).

\section{Results}

\subsection{Answering of Research Questions}

Mean and Standard Deviation were used in answering the research questions and the summary of the data are shown below in the tables

\subsection{Research Question 1}

What is the difference in the academic performance of Educational Technology year two students taught with Smart Slate Game technology and those taught using expository method. 
Journal of Education and Practice

ISSN 2520-467X (Online)

Vol.6, Issue No.1, pp 1 - 18, 2022

WWW.carijournals.org

Table 1: The table below shows the Mean and Standard Deviation Scores of the difference that exists in the academic performance of Educational Technology year two students taught with

Smart Slate Game technology and those taught using expository method

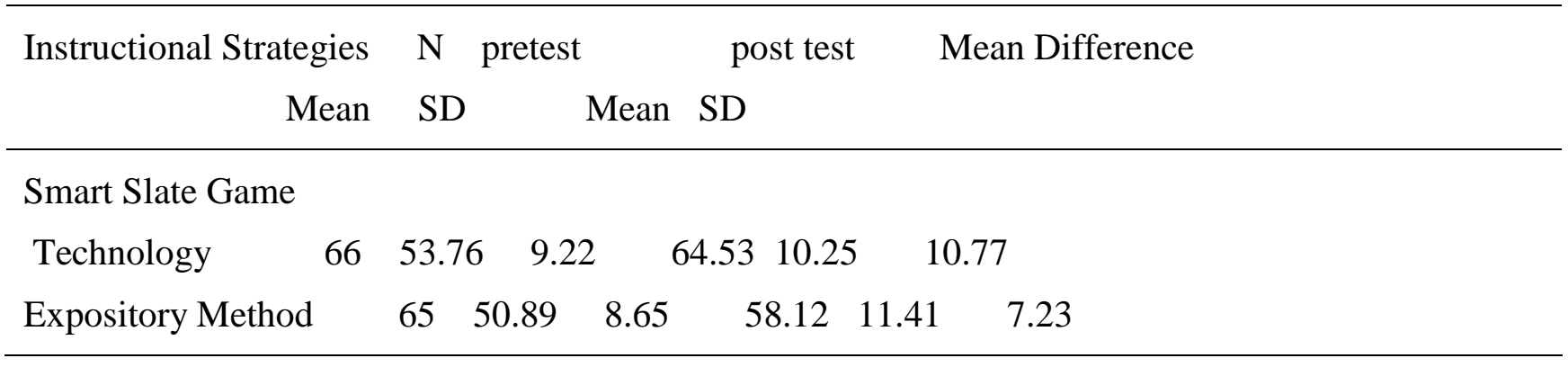

The result of table 1 revealed that the mean difference in academic performance of students taught using Smart Slate Game technology was 10.77 while that of the students taught with the expository method was 7.23. This means that students taught with Smart Slate Game technology therefore performed better than students taught using expository method did.

\subsection{Research Question 2}

What is the difference in the academic performance of Educational Technology year two students taught using Smart Slate Game Technology in the University of Calabar based on Gender?

Table 2: Mean and Standard Deviation of the Academic Performance of Educational Technology Students Taught using Smart Slate Game technology based on Gender.

\begin{tabular}{|c|c|c|c|c|c|c|}
\hline \multirow{2}{*}{ Gender } & \multicolumn{2}{|c|}{ Pre-test } & Post-test & \multicolumn{3}{|c|}{ Mean Difference } \\
\hline & Mean & SD & Mean SD & & & \\
\hline Male & 26 & 53.47 & 9.34 & 68.71 & 10.67 & 15.24 \\
\hline Female & 40 & 47.86 & 7.9261 .53 & 8.41 & 13. & \\
\hline
\end{tabular}

The result of Table 2 revealed that the mean difference for academic performance of male students taught using Smart Slate Game technology was 15.24 while that of the female counterpart was 13.67.This means that male students taught using Smart Slate Game technology slightly performed better than the female students.

\subsection{Research Question 3}

What is the difference in the academic performance of Educational Technology year two students taught using Smart Slate Game technology and those taught with expository method based on Cognitive ability level? 
Journal of Education and Practice

ISSN 2520-467X (Online)

Vol.6, Issue No.1, pp 1 - 18, 2022

WWW.carijournals.org

Table 3: Mean and Standard Deviation of academic performance of Educational Technology students when taught Using Smart Slate Game technology based on Cognitive Ability level

Cognitive N Pre-test Post-test Mean Difference

Ability

Level

Mean

SD Mean

SD

Low

$23 \quad 39.02$

$\begin{array}{ll}7.32 & 72.39\end{array}$

8.93

33.37

Moderate

$34 \quad 46.72$

$5.21 \quad 69.88$

7.62

23.16

$\begin{array}{lllllll}\text { High } & 9 & 52.41 & 3.34 & 75.16 & 4.54 & 22.75\end{array}$

The result in Table 3 revealed the mean difference in academic performance of high, moderate and low abilities of students taught using Smart Slate Game technology. The result shows that the mean difference of low ability students of 33.37 was greater than that obtained by moderate ability students of 23.16 , which was also greater than the mean score of 22.75 obtained by high ability. This means that there is small difference in academic performance of educational technology students when taught using Smart Slate Game technology based on cognitive ability levels.

\section{Testing of the Hypotheses}

ANCOVA statistical tool was used for testing all the hypotheses at .05 level of significance.

3.1 There is no significant difference in the academic performance of Educational Technology year two students taught with Smart Slate Game technology and those taught with expository method. 
Journal of Education and Practice

ISSN 2520-467X (Online)

Journals

Vol.6, Issue No.1, pp 1 - 18, 2022

www.carijournals.org

Table 4: Summary of Analysis of Covariance of the Performance of students taught with

Smart Slate Game Technology and those taught with expository method

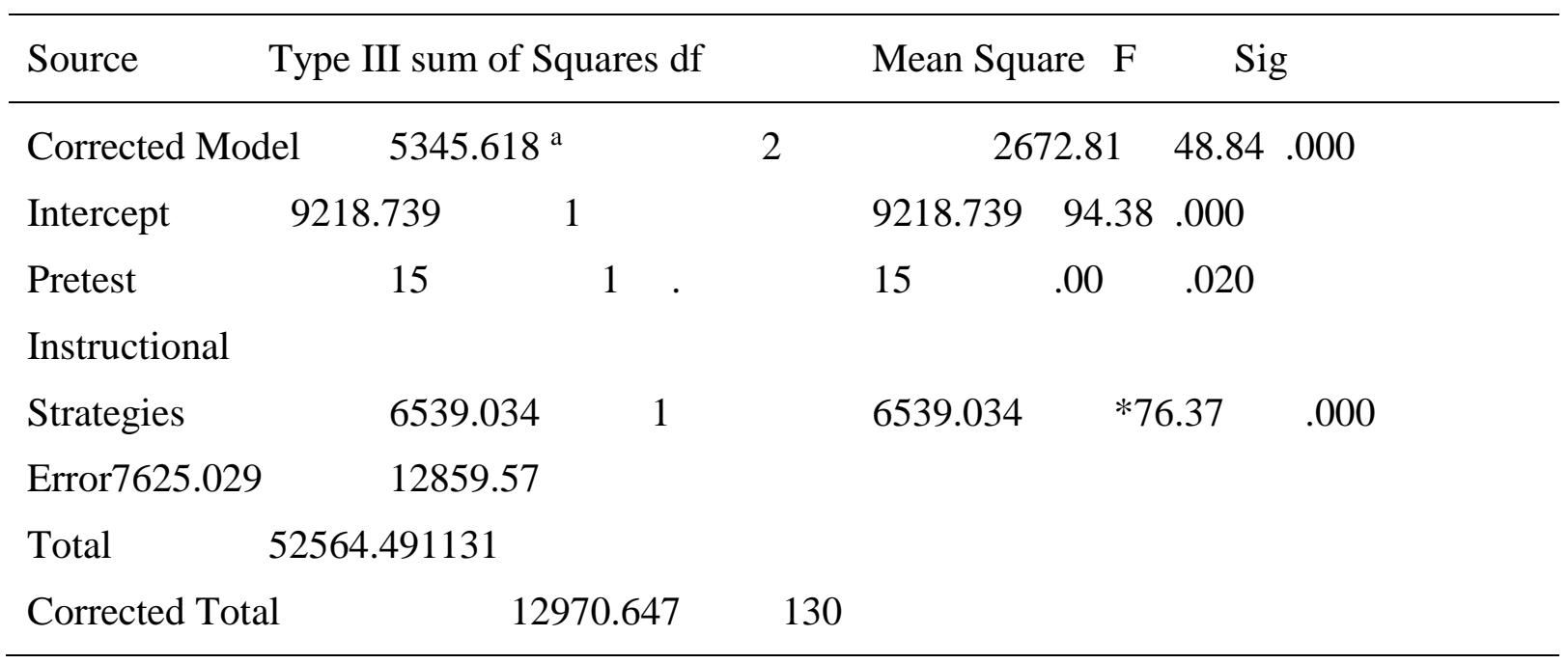

a. $\mathrm{R}$ Squared $=.426$ (Adjusted R Squared $=.406$ ); F - crit $=3.96$

The result in Table 4 reveals that the calculated F-value of 76.37 is greater than the critical Fvalue of 3.96 at 1 and 129 degree of freedom and at .05 level of significance. With this result, the null hypothesis was rejected. This implies there is a significant difference in academic performance of educational technology students when taught using Smart Slate Game technology and those taught with expository method.

\subsection{Hypothesis Two}

There is no significant difference in the academic performance of male and female Educational Technology year two students taught using Smart Slate Game technology in the University of Calabar.

Table 5: Result of ANCOVA Analysis of the Difference in the Academic Performance of Educational Technology year two students taught Using Smart Slate Game technology based on Gender

Sources Type III Sum Df. Mean Square F-cal Sig.

of Squares

\begin{tabular}{lccccccc}
\hline Corrected & \multicolumn{2}{c}{$356.38^{\mathrm{a}}$} & \multicolumn{2}{c}{2178.19} & 3.81 & .07 \\
Model & & & & & & & \\
Intercept & 7132.603 & 1 & 7132.603 & 132.21 & .00 & \\
Pre-test & 15.79 & 1 & 15.79 & .43 & .52 & & \\
Gender & 352.45 & 1 & 352.45 & 9.61 & .02 & & \\
Error & 4328.12 & 64 & & 67.63 & & \\
Total & 54616.74 & 66 & & & & \\
Corrected & & & & & & & \\
Total & 4684.50 & 65 & & & &
\end{tabular}


Journal of Education and Practice

ISSN 2520-467X (Online)

www.carijournals.org

Vol.6, Issue No.1, pp 1 - 18, 2022

a. R Squared $=.209$ (Adjusted R Squared $=.096$ ); F-crit. $=4.08$

The result of the table 5 indicated that the calculated $t$ value of 9.61is greater than the critical F-value of 4.08 at 1 and 64 degree of freedom and at .05 level of significance. With this result, the null hypothesis was retained. This implies that there is a significant difference in the academic performance of educational technology students taught using Smart Slate game technology based on gender.

\subsection{Hypothesis Three}

There is no significant difference in the academic performance of Educational Technology year two students taught with Skooly technology and those taught with expository method based on low, moderate and high cognitive ability.

Table 6: Result of ANCOVA Analysis of the Difference in Academic Performance of Educational Technology Students when Taught Using Smart Slate Game technology on Cognitive Ability levels

\begin{tabular}{|c|c|c|c|c|c|c|c|c|c|}
\hline \multicolumn{2}{|l|}{ Source } & \multicolumn{2}{|c|}{$\begin{array}{l}\text { Type III Sum } \\
\text { Of Squares }\end{array}$} & Df. & \multicolumn{3}{|c|}{ quare } & \multirow[t]{2}{*}{$\mathrm{F}$} & \multirow[t]{2}{*}{ Significant } \\
\hline Corrected Mod & & 324.99 & 13 & 108.33 & 1.78 & .24 & & & \\
\hline Intercept & \multicolumn{2}{|c|}{2178.27} & 1 & 2178.27 & 56.28 & & .00 & & \\
\hline Pretest & 75.52 & 1 & 75.52 & 1.66 & .21 & & & & \\
\hline \multicolumn{3}{|c|}{ Cognitive_ability_level 314.20} & 2 & 157.10 & 2.71 & .14 & & & \\
\hline Error & \multicolumn{2}{|c|}{1968.03} & 62 & & 12.07 & & & & \\
\hline Total & \multicolumn{2}{|c|}{56374.00} & 66 & & & & & & \\
\hline \multicolumn{3}{|l|}{ Corrected Total } & & & & & & & \\
\hline
\end{tabular}

a. $\mathrm{R}$ Squared $=.202$ (Adjusted R Squared $=.032$ ); F-crit. $=4.08$

The result in Table 6 reveals that the calculated $F$ value of 2.71 is less than the critical $F$ value of 4.08 at 1 and degrees of freedom with .05 level of significance. With this result, the null hypothesis was retained. This implies that there is no significant difference in the academic performance of Educational technology students when using Smart Slate Game technology on cognitive ability level.

\section{Summary of Findings}

1. There is a significant difference in academic performance of educational technology students when taught using Smart Slate Game and those taught with expository method.

2. There is a significant difference in the academic performance of educational technology students taught using Smart Slate game technology based on gender.

3. There is no significant difference in the academic performance of Educational technology students when using Smart Slate Game technology on cognitive ability levels. 
Journal of Education and Practice

ISSN 2520-467X (Online)

Vol.6, Issue No.1, pp 1 - 18, 2022

www.carijournals.org

\section{Discussion of Results}

In this section, the results of the study were discussed variable by variable

\section{$5.1 \quad$ Hypotheses One}

The result of the first finding revealed that there is a significant difference in academic performance of educational technology students when taught using Smart Slate Game and those taught with expository method. This could be due to the cueing effects that characterized the use of Smart Slate Game technology because students get motivated when they learn with funs. This finding is in line with McClarty (2012) ${ }^{[1]}$ that when students' use Smart Slate Electronic Game in learning, it would increase their learning outcome. According to de Smale (2015) ${ }^{[2]}$, a positive relationship existed between the use of Smart Slate Electronic Game and students' academic performance in the subject being taught. To test for the effect of Smart Electronic Game as a supplementary element in collaborative learning, Ritu $(2015)^{[4]}$ notes that when students used Smart Slate Game in-group to learn, it assists in developing higher-level thinking, oral communication, self-management and leadership skills. In view of this, Ke \& Grabowski (2009) ${ }^{[5]}$ in their study on a sample size of 125 students divided into collaborative groups who were competing. The students took a test before and after the experiment. The research result indicated that playing Smart Slate Electronic Game was more efficient than through traditional tasks.

\subsection{Hypotheses Two}

The result of the second findings revealed that gender has significantly affected educational technology year 2 students' performance when using Smart Slate Game technology in learning educational technology courses. The finding is also in line with Oluwatayo (2011) ${ }^{[9]}$ who reported that males had a larger variance in Physics scores than females. Moreover, females tended to outperform males among the low achieving students, while males tended to outperform females among the high achieving students. This is also opposed by Papastergeus (2019) ${ }^{[21]}$ in his study of 88 students drawn by gender into two groups. One played a Smart Slate Game and the other did not. He conducted a computer pretest and posttest to access their knowledge, the result which initially proved male dominance was not significant regardless of the gender of students.

\subsection{Hypotheses Three}

The result of the third analysis of the difference in academic performance of educational technology students when taught using Smart Slate Game technology based on cognitive ability level revealed that there is no significant difference in the academic performance of Educational technology students when using Smart Slate Game technology based on cognitive ability level. Smart Slate Game technology had the utmost effect on the students with low ability than their counterpart in moderate and high ability level. This could be attributed to low ability, students having high cueing effects on the instructional package during the Smart Slate Game interactive sessions. This was immensely achieved with graphics, colour and illustrated diagrams. The design package helped educational technology year two students stay focus and concentrate to learn from the instructional package. The cognitive ability helps the students in memory recall and retention, which enhances high level of learning experience among the students. However, the finding is in line with Ayoud (2019) ${ }^{[8]}$ who posited that students might ask questions during the Smart Slate Game session to help them structure their sentences or do their assignments before posting them. This also opposed Von, Van der Meijden \& Denessen $(2011)^{[7]}$ support this finding in their activity for cognitive abilities in the use of Smart Slate Game by experimenting on 235 students. One group was asked to create their own game 'Smart Slate' while the other group displayed the 
Journal of Education and Practice

ISSN 2520-467X (Online)

Vol.6, Issue No.1, pp 1 - 18, 2022

WWW.carijournals.org

existing game type. The results suggest that designing a game could be better way to improving the cognitive abilities and increasing students' performance in educational technology pedagogy.

\section{Conclusion}

Educational innovation has become a necessity in the modern classroom system. The issue concerning the simpler way to motivate learners to learn with fun lies in the introduction and integration of Smart Slate Electronic game into teaching and learning encounter group. This will help the students to accomplish the task of pedagogy. Many researchers have found instructional game to be useful arresting the minds of learners and channeling their interests and energies productively which originally would have been driven to unprofitable ventures. The emerging issue on how to improve students' academic performance lies in the motivational drive on instructors' use of the Smart Slate Electronic Game technology to design lessons for educational technology students in the universities especially the University of Calabar. The findings of this study have shown that when lecturers effectively use Smart Slate Electronic Game in teaching, it would help to improve and sustain students' cognitive learning abilities; students' gender based discrepancies as it comes to learning and also contributes to high performance of educational technology students in the Universities.

\section{Recommendation}

Based on the findings of this study, the following recommendations were made:

1. Teachers should effectively design their lesson plans with Smart Slate Electronic Game technology since the essence is to foster group task so as to encourage learners to have fun while learning.

2. The designers of the curriculum should ensure that Smart Slate Electronic Game based instruction is adopted as a learner-centred instructional strategy in higher institutions without the disparity in gender to encourage dynamism and diversification in instructional techniques other than rote methods.

3. The study has proven the importance of students' cognitive abilities in the use of Smart Slate Electronic Game technology during lesson. Therefore, lecturers should consider the ability level of learners in the designing process before taking instruction to the classrooms.

\section{References}

[1] McClarty, R. L. (2012). A literature review of Gaming in Education: Gaming in Education, 1 -35.

[2] De Smale S. (2015). The effect of simulations and games on learning objectives in Tertiary Education; A systematic review. Springer International Publishing Switzerland, pp. 506-516. Dol: 1010007/978- 319-4021-1-55.

[4] Ritu, G. P. (2013). Gaming industry, social responsibility and academia. Casino and Gaming International 3(3):97-103

[5] Ke, F \& Grabowski, B (2006). Game playing for Maths learning: Cooperative or not. British Journal of $\quad$ Educational Technology, 38(2); 249-259.

[6] Hirumi, M. \& Bai, H (2010). The effects of modern mathematic computer games on mathematics achievement and class motivation. Computer \& Education, 55(2); 427-443. 
Journal of Education and Practice

ISSN 2520-467X (Online)

Vol.6, Issue No.1, pp 1 - 18, 2022

WWW.carijournals.org

[7] Von, N, Meijden, V. H \& Denssen (2011). Effects of constructing versus playing an educational game on student anowtach and deep learning strategy use. Computers \& Education, 56(1): 127-137.

[9] Oluwatayo, J.A. (2011). Self-concept and performance of secondary school students in mathematics. Journal of educational and developmental psychology, 1(1),1-10.

[10] Anand, V. (2007). A study of time management: The correlation between video game usage and academic performance markers. Cyber Psychology \& Behaviour, 10(4), 552-559.

[11] Smyth, J. M. (2007). Beyond self-selection in video game-play: An experimental Examination of the consequences of massively multiplayer online role-playing game play. Cyberpsychological \& Behaviour, 10: 717-721.

[12] Skoric, M. M, Teo, L. L, Neo \& R. L (2009). Children and video games: addiction, engagement, and scholastic achievement. Cyber psychological behaviour, 12(5): 567-572.

[13] Anderson, C. A. \& Dill-Shackleford, K. E. (2007). Video Games and Aggressive Thoughts, Feelings and Behaviour in the Laboratory and in Life. Journal of Personality and Social Psychology. 78(4):772-90.

[14] Wack, E \& Tantleff-Dunn, S. (2009). Relationships between Electronic Game Play, Obesity and Psychological Functioning in Young Men. Cyber Psychology \& Behavoiur, $12,241-244$.

[15] Jackson ,L.A., Alexander, V. E, Witt, E \& Yong Zhao (2008). A longitudinal study of the effects of internet use and video game playing on academic performance and roles of gender, race and income in these relationships. Computer in Human Behavior, 27(1): 228-239.Chandra, R (2015). Classroom Management for effective teaching. International Journal of Education and Psychological Research, 4(4):13-15.

[16] Wood, R.T.A,. Griffiths, M. D., Parke, J. \& Parke, A. (2007). Gaming research and best practice: Gaming industry, social responsibility and academia. Casino and Gaming International 3(3): 97-103

[17] Williams, E. L. (2006). The automaticity of social life. Current directions in psychological science 15(1):1-4.

[18] Effiong, A. A. \& Ekpo, E. O. (2016). Interactive effect of PowerPoint instructional package and academic performance of educational technology students in the University of Calabar. Equatorial of $\quad$ Education and Curriculum Studies, 1(2):1-12

[19] Ukwetang, J. O, Nja, C. O, Eneyo, E, Ambe, B. A. \& Etta, A. B. (2021). Usage of Information Communication Technology (ICT) and Academic Performance of Students in Tourism in Selected Secondary Schools in Calabar Municipality in Cross River State, Nigeria. European Journal of Social Sciences, 62(3):79-88.

[20] Okworo, G. S. \& Effiong, A.A. (2020). Use of Teachers made YouTube Instructional Video Package and Students Performance in Educational Technology in University of Calabar. COVID-19 Pandemic: The pendulum of reconstruction of instructional system in Nigeria.

Mayer, R. E., \& Moreno, R. (2003). Nine ways to reduce cognitive load in multimedia learning. Educational Psychologist 38(1):43-52. 
Journal of Education and Practice

ISSN 2520-467X (Online)

Vol.6, Issue No.1, pp 1 - 18, 2022

WWW.carijournals.org

Walberg, H. J. (1981). Educational productivity; theory, evidence and prospects. Australian Journal of Education. https://doi.org/10.1177/000494418202600202.

\section{Authors}

1. Effiong Abigail Aniefiok (PhD) is a lecturer in the Department of Curriculum and Teaching (Educational Technology unit) University of Calabar. She has a Masters degree in Educational Technology from the department of Educational Technology and Library Science in the University of Uyo. She also have a Bachelor's degree in Educational Technology from the University of Calabar. She has scholarly articles published reputable journals. Her research interests are in Instructional System Design and Resource-Based Learning. e is a member of some professional bodies including Educational Media and Technology Association of Nigeria and Curriculum Association of Nigeria. She has equally attend several conferences, workshops and seminars in Educational Technology and other related fields.e is a member of some professional bodies including Educational Media and Technology Association of Nigeria and Curriculum Association of Nigeria. He has equally attend several conferences, workshops and seminars in Educational Technology and other related fields.

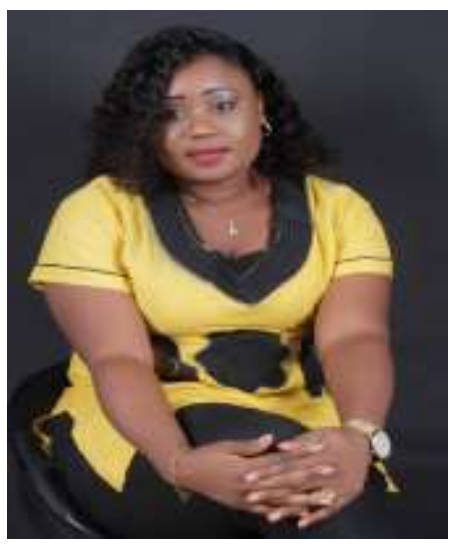

2. Ekpo-Eloma, E.O is a lecturer in the department of Curriculum and Teaching, Faculty of Educational Foundation Studies, University of Calabar, Nigeria. He has a B.Ed ( Hons) degree in public administration all from the University of Calabar, Nigeria; M.Sc (Ed) in Educational Technology and a PhD in View. His research interests are in Instructional System Design (ISD), Broadcasting and Scripting for the Media, Digital Education and Education Resource Center and Management.

$\mathrm{He}$ is a member of some professional bodies including Educational Media and Technology Association of Nigeria and Curriculum Association of Nigeria. He has equally attend several conferences, workshops and seminars in Educational Technology and other related fields. 
Journal of Education and Practice

ISSN 2520-467X (Online)

Vol.6, Issue No.1, pp 1 - 18, 2022

www.carijournals.org

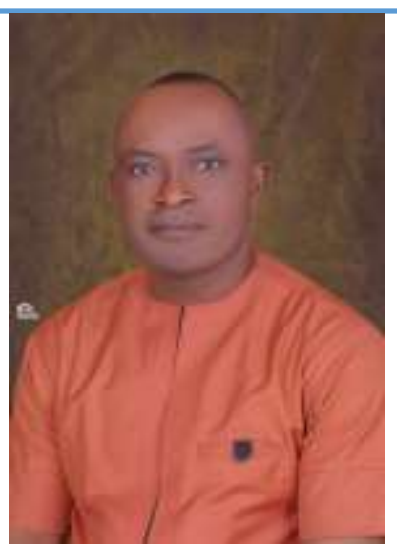

3. Jacob Kirian James is a PhD student in the Department of Educational Technology and Library Science in the University of Uyo, Uyo. He has a Masters degree in Educational Technology from the National Open University and a Bachelor's degree in Educational Technology from the University of Calabar. He research interest is in Instructional System Design. He is also a member

of the Educational Technology and Media Association

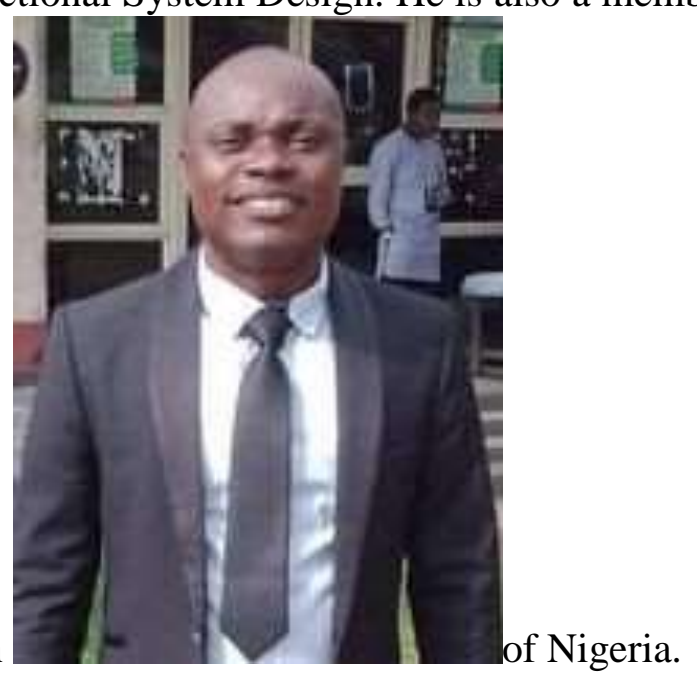

4. Udoh Victoria Inebehe is a Masters student in the Department of Educational Technology and Library Science in the University of Uyo, Uyo, Nigeria. She has a Bachelors degree in Educational Technology from the University of Calabar. Her research interests are in Instructional System Design and Educational Broadcasting and Scripting for the Media. She is also a member of Educational Technology and Media Association of Nigeria. 
Journal of Education and Practice

ISSN 2520-467X (Online)

Vol.6, Issue No.1, pp 1 - 18, 2022

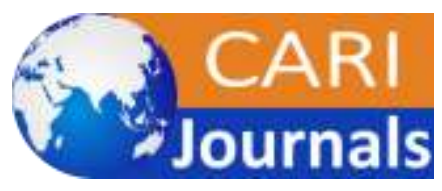

www.carijournals.org

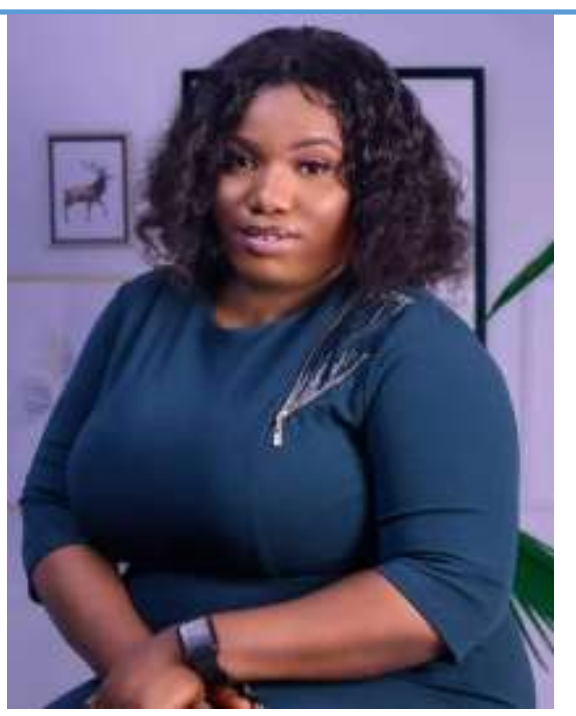

